\title{
28. QUANTITY, PROVENANCE, AND THERMAL MATURITY OF ORGANIC MATTER FROM THE NEW JERSEY CONTINENTAL MARGIN, DEEP SEA DRILLING PROJECT LEG 951
}

\author{
Rüdiger Stein, Jürgen Rullkötter, Wolfgang Kalkreuth, and Dietrich H. Welte, \\ Institute of Petroleum and Organic Geochemistry, Jülich ${ }^{2}$
}

\begin{abstract}
Using methods of analysis from organic geochemistry and organic petrography, we investigated six Pliocene to Maestrichtian samples from DSDP Site 612 and five Pliocene to Eocene samples from DSDP Site 613 for the quantity, type, and thermal maturity of organic matter.

At both sites, organic carbon content is low in the Eocene samples $(0.10$ to $0.20 \%)$ and relatively high in the Pliocene/Miocene samples $(0.87$ to $1.15 \%)$. The Maestrichtian samples from Site 612 contain about $0.6 \%$ organic carbon. The organic matter is predominantly terrigenous, as indicated by low hydrogen index values from Rock-Eval pyrolysis and the dominance of long-chain wax alkanes in the extractable hydrocarbons. The organic matter is at a low level of thermal maturity; measured vitrinite reflectance values were between 0.27 and $0.44 \%$.
\end{abstract}

\section{INTRODUCTION}

In order to complete a transect of the Baltimore Canyon Trough encompassing the continental slope and rise of New Jersey, two sites were drilled off the coast of New Jersey during DSDP Leg 95 (Sites 612 and 613; Fig. 1). The age and lithology of the sediments recovered at Sites 612 and 613 are summarized in Figure 2 (see also the site chapters, this volume).

The purpose of this study was to describe the amount, type, and composition of the organic matter in the sediments. The results are discussed in terms of origin, depositional environment, and thermal maturity. We investigated six samples of Pliocene to Maestrichtian age from Site 612 and five samples of Pliocene to Eocene age from Site 613 (Fig. 2).

\section{ANALYTICAL PROCEDURES}

The frozen samples were dried at $50^{\circ} \mathrm{C}$ for $12 \mathrm{hr}$. and ground. Total organic carbon was determined with a LECO IR-112 carbon analyzer after the sediments were treated with hydrochloric acid to remove the carbonate carbon. Extraction was performed using a modified flowblending technique (Radke et al., 1978) and with dichloromethane as the extraction solvent. The total extracts were separated into monoaromatic hydrocarbons, aromatic hydrocarbons, and heterocomponents by automated medium-pressure liquid chromatography (Radke et al., 1980).

A Siemens L350 gas chromatograph equipped with a $23 \mathrm{~m} \times 0.3 \mathrm{~mm}$ inner diameter (ID) glass capillary column coated with SE54 was used for gas chromatographic $(\mathrm{GC})$ analysis of the nonaromatic hydrocarbon fractions. Helium was used as carrier gas. The temperature program was as follows: $80^{\circ} \mathrm{C}$ for 2 min.; 80 to $254^{\circ} \mathrm{C}$ at a rate of $3{ }^{\circ} \mathrm{C} /$ min.; isothermal at $254^{\circ} \mathrm{C}$ for $25 \mathrm{~min}$.

Gas chromatography/mass spectrometry (GC/MS) was carried out on a VG $7070 \mathrm{E}$ mass spectrometer linked directly to a Carlo Erba Fractovap model 4160 gas chromatograph via an open-split coupling. Samples were injected splitless onto a $25 \mathrm{~m} \times 0.3 \mathrm{~mm}$ ID fused silica column coated with SE54. Helium was used as carrier gas, and the

\footnotetext{
${ }^{1}$ Poag, C. W., Watts, A. B., et al., Init. Repts. DSDP, 95: Washington (U.S. Govt. Printing Office).

Addresses: (Stein, present address) Institut für Geowissenschaften und Lithosphärenforschung, Universität Giessen, Senckenbergstrasse 3, 6300 Giessen, Federal Republic of Germany; (Rullkötter, Kalkreuth, Welte) Institute of Petroleum and Organic Geochemistry, Kernforschungsanlage Jülich GmbH, D-5170 Jūlich, Federal Republic of Germany.
}

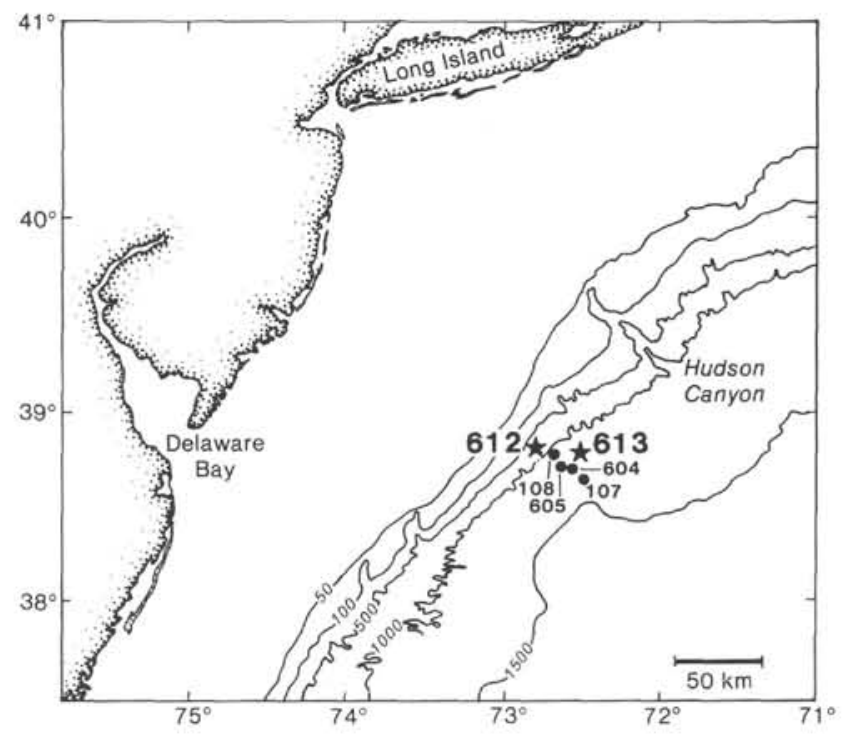

Figure 1. Locations of DSDP Sites 612 and 613 (Leg 95), Sites 604 and 605 (Leg 93), and Sites 107 and 108 (Leg 11). Bathymetry in m.

temperature was raised from 70 to $300^{\circ} \mathrm{C}$ at a rate of $4^{\circ} \mathrm{C} / \mathrm{min}$. The mass spectrometer was operated at an ionization energy of $80 \mathrm{eV}$. The source temperature was kept at $220^{\circ} \mathrm{C}$, and the magnet scanned continuously at a rate of $3 \mathrm{~s}$ per scan. All data were stored and processed using a DS 55 on-line data system (Kratos AEI).

Rock-Eval pyrolysis was performed according to the method described by Espitalié et al. (1977). Hydrogen and oxygen contents of the rock samples, measured as hydrocarbon-type compound and carbon dioxide yields, respectively, were normalized to organic carbon and displayed as index values in a diagram adopted from Espitalié et al. (1977) and Roucaché et al. (1979).

The kerogen separation procedure included treatment with $7.5 \mathrm{~N}$ $\mathrm{HCI}$ and HF. The maceral types were analyzed using both transmitted and normal or fluorescence reflected light. Vitrinite reflectance (at $546 \mathrm{~nm}$ in oil) was measured on particles larger than $10 \mu \mathrm{m}$.

\section{RESULTS}

\section{Organic Carbon}

The total organic carbon (TOC) contents of the six samples from Site 612 vary between 0.17 and $1.11 \%$ 


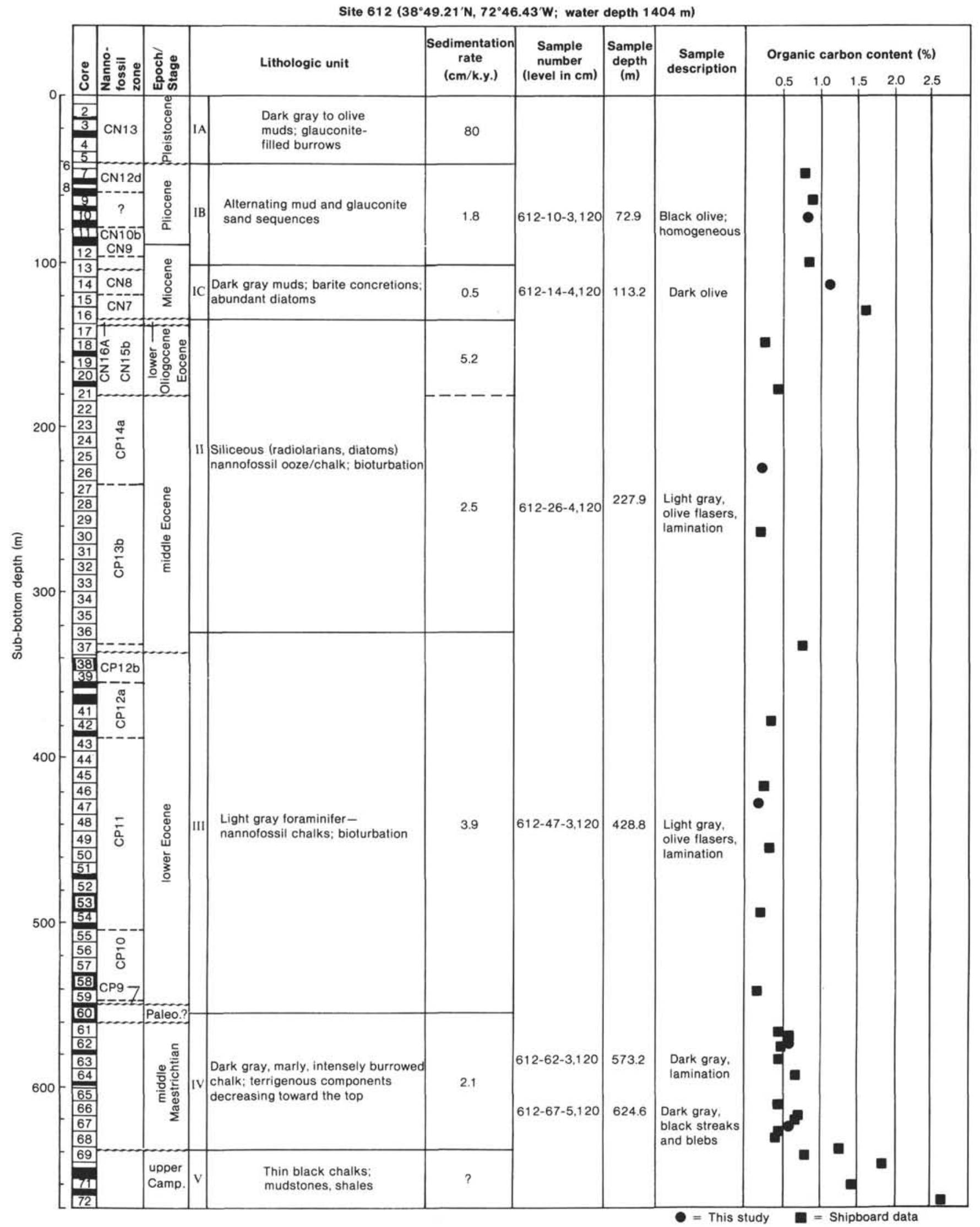

Figure 2. Summary of stratigraphy, lithology, and sedimentation rates for DSDP Sites 612 and 613. Samples investigated in this study are as described. 
Site $613\left(38^{\circ} 46.26^{\prime} \mathrm{N}, 72^{\circ} 30.43^{\prime} \mathrm{W}\right.$; water depth $\left.2323 \mathrm{~m}\right)$

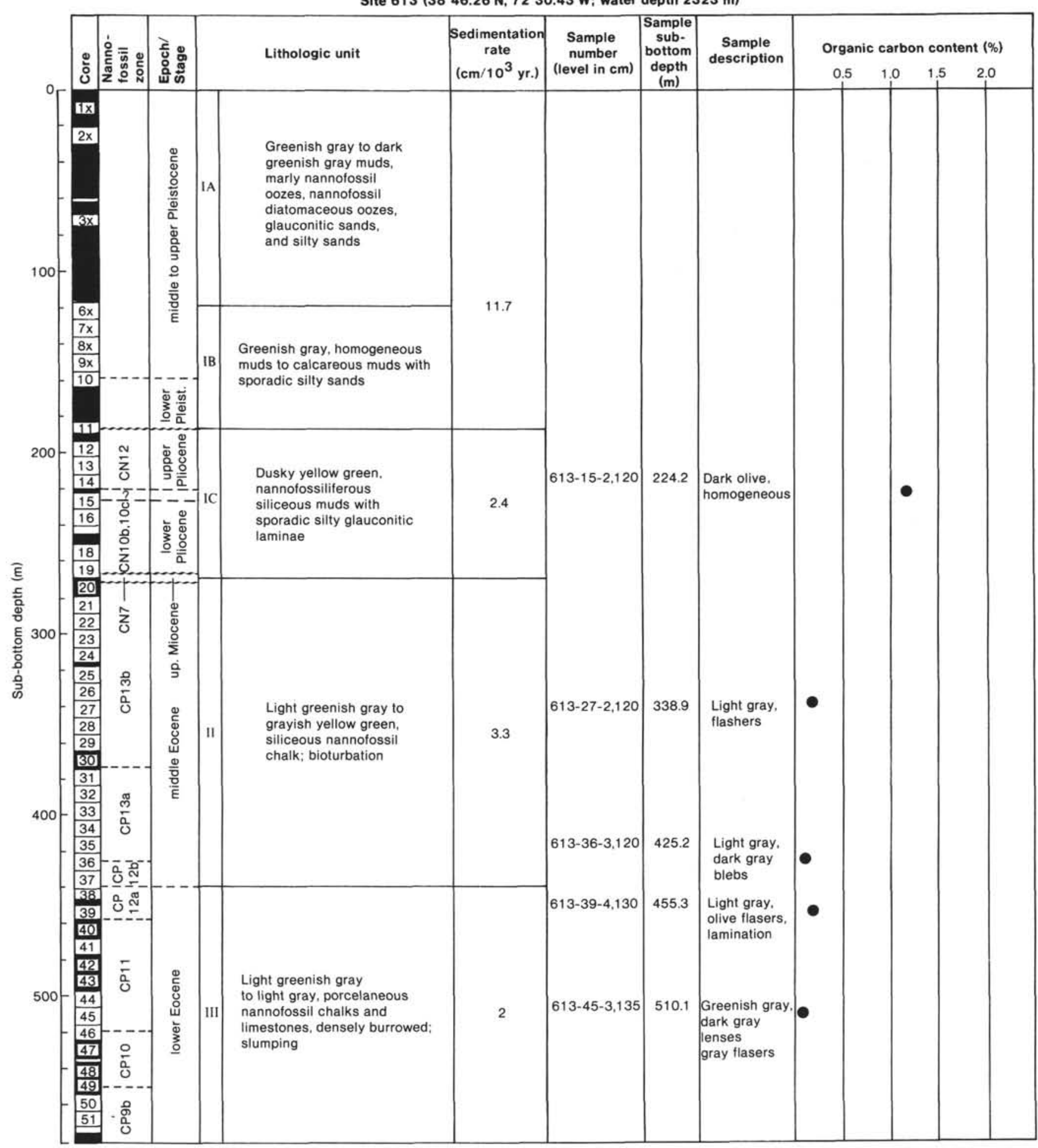

Figure 2 (continued).

(Fig. 2, Table 1). These values agree very well with the shipboard TOC data (Fig. 2). According to the TOC data, the sediment sequence of Site 612 can be divided into five intervals: (1) a Pleistocene/Pliocene interval (corresponding to lithologic Units IA and IB) with TOC values between 0.78 and $0.93 \%$ (mean $0.85 \%$ ); (2) a Mio- cene interval (corresponding to lithologic Unit IC) with TOC values of 1.11 and $1.58 \%$ (mean $1.34 \%$ ); (3) an Eocene interval (corresponding to lithologic Units II and III) with very low TOC values of less than $0.50 \%$ (mean $0.30 \%$ ); (4) a Maestrichtian interval (corresponding to lithologic Unit IV) with TOC values between 0.47 and 
Table 1. Stratigraphy, organic carbon, pyrolysis, extract and liquid chromatography data for samples from DSDP Leg 95.

\begin{tabular}{|c|c|c|c|c|c|c|c|c|c|c|}
\hline \multirow[b]{3}{*}{$\begin{array}{c}\text { Sample } \\
\text { (interval in } \mathrm{cm} \text { ) }\end{array}$} & \multirow{3}{*}{$\begin{array}{c}\text { Sub-bottom } \\
\text { depth }(m) \\
\text { of top of } \\
\text { sample }\end{array}$} & \multirow[b]{3}{*}{ Age } & \multirow{3}{*}{$\begin{array}{l}\text { Organic } \\
\text { carbon } \\
\text { (wt. \%) }\end{array}$} & \multirow{2}{*}{\multicolumn{3}{|c|}{ Rock-Eval pyrolysis }} & \multirow[b]{3}{*}{$\begin{array}{c}\text { Extract } \\
\left(\mathrm{mg} / \mathrm{g} C_{\text {org }}\right)\end{array}$} & \multicolumn{3}{|c|}{ Liquid chromatography fractions } \\
\hline & & & & & & & & & Aromatic & Hetero- \\
\hline & & & & $\begin{array}{l}\text { Hydrogen index } \\
\text { (mg HC/g C } \text { org }^{\text {(m }}\end{array}$ & $\begin{array}{c}\text { Oxygen index } \\
\text { (mg CO } 2 / \mathrm{g} \mathrm{C}_{\text {org }} \text { ) }\end{array}$ & $\begin{array}{l}T_{\max } \\
\left({ }^{\circ} \mathrm{C}\right)\end{array}$ & & $\begin{array}{c}\text { Aliph. HC } \\
(\%)\end{array}$ & $\begin{array}{l}\text { hydrocarbons } \\
(\%)\end{array}$ & $\begin{array}{c}\text { components } \\
(\%)\end{array}$ \\
\hline $612-10-3,120-134$ & 72.9 & Pliocene & 0.87 & 164 & 173 & 413 & 10.8 & 12.0 & 2.1 & 85.9 \\
\hline $612-14-4,120-135$ & 113.2 & late Miocene & 1.11 & 243 & 170 & 421 & 16.1 & 9.9 & 3.5 & 86.6 \\
\hline $612-26-4,120-135$ & 227.9 & middle Eocene & 0.20 & 137 & a & 412 & 15.2 & 26.7 & 13.3 & 60.0 \\
\hline $612-47-3 \quad 120-135$ & 428.8 & early Eocene & 0.17 & 152 & a & 415 & 23.0 & 8.8 & 5.9 & 85.3 \\
\hline $612-62-3,120-133$ & 573.2 & Maestrichtian & 0.59 & 42 & 348 & 412 & 4.4 & 6.7 & 3.3 & 90.0 \\
\hline $612-67-5,120-133$ & 624.6 & Maestrichtian & 0.57 & 47 & 343 & 410 & 5.1 & 6.3 & 3.1 & 90.6 \\
\hline $613-15-2,120-134$ & 224.2 & Pliocene & 1.15 & 138 & 259 & 417 & 7.4 & 8.8 & 1.0 & 90.2 \\
\hline $613-27-2,120-135$ & 338.9 & middle Eocene & 0.17 & 82 & a & 369 & 8.0 & 12.5 & 6.3 & 81.2 \\
\hline $613-36-3,120-135$ & 425.2 & middle Eocene & 0.14 & 109 & a & 410 & 52.4 & 64.9 & 7.4 & 27.7 \\
\hline $613-39-4,130-145$ & 455.3 & early Eocene & 0.17 & 97 & a & 382 & 9.0 & 14.3 & 7.1 & 78.6 \\
\hline $613-45-3,135-150$ & 510.1 & early Eocene & 0.10 & 103 & a & 393 & 19.8 & 31.6 & 26.3 & 42.1 \\
\hline
\end{tabular}

a All oxygen index values are greater than 900 .

$0.73 \%$ (mean $0.57 \%$ ); and (5) an upper Campanian interval (corresponding to lithologic Unit V) with high TOC values between 0.80 and $2.68 \%$ (mean $1.62 \%$ ) (Fig. 2).

For Site 613, no shipboard TOC data exist. The five samples we investigated have an organic carbon content of between 0.10 and $1.15 \%$ (Fig. 2, Table 1). The moderately high TOC value of $1.15 \%$ is from the Pliocene (lithologic Unit IC). As in the Eocene samples of Site 612 , the TOC values of the Eocene samples of Site 613 range from 0.10 to $0.17 \%$. The low organic carbon content at both sites during Eocene times is in agreement with the TOC determined at the neighboring Site 108, where the values for the Eocene sediments vary between 0.1 and $0.3 \%$ (Boyce, 1972).

\section{Type and Maturity of Organic Matter}

The results of the Rock-Eval pyrolysis (Espitalié et al., 1977) are shown in Figure 3 and Table 1. In Figure 3, we have only presented data derived from samples with TOC contents greater than $0.5 \%$. The results for the six Eocene sediment samples that contain organic carbon below $0.2 \%$ (Table 1 ) were rejected because the extremely high oxygen indices determined for these organic-carbon-lean samples are questionable (Katz, 1983).

The hydrogen index values are low to moderate and range from $42 \mathrm{mg} \mathrm{HC} / \mathrm{g} \mathrm{C}_{\text {org }}$ in the Maestrichtian to $243 \mathrm{mg} \mathrm{HC} / \mathrm{g} \mathrm{C}_{\text {org }}$ in the Miocene (Fig. 3, Table 1). The oxygen index values vary between 170 and $348 \mathrm{mg} \mathrm{CO} /$ $\mathrm{g} \mathrm{C}_{\text {org. }}$. According to Figure 3, the organic matter in the Pliocene and Maestrichtian samples investigated is characterized as kerogen type III, and the organic matter of the Miocene sample of Site 612 may represent a mixture of types II and III. In the Eocene samples of Sites 612 and 613, kerogen type III appears to be dominant, as implied by hydrogen index values of less than $150 \mathrm{mg}$ $\mathrm{HC} / \mathrm{g} \mathrm{C}_{\text {org }}$ (Table 1).

The results of the kerogen microscopy are disappointing because the kerogen isolation yields were too low to allow quantitative estimates of the maceral composition of the organic matter. Some of the finely dispersed amorphous material may have been lost during the separation procedure. Qualitative results were obtained from only two samples (Table 2). The Miocene sample (612-14-4, $120-135 \mathrm{~cm}$ ) contains debris of terrestrial plant tissue

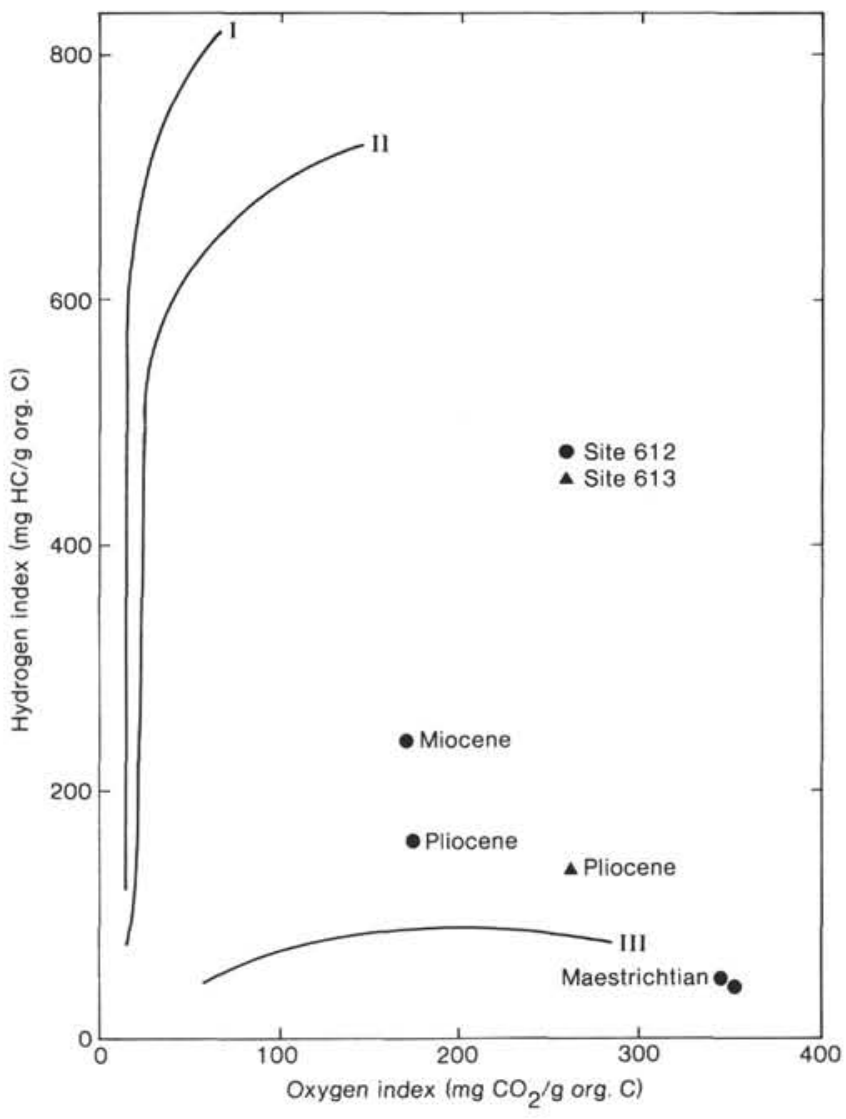

Figure 3. Results of Rock-Eval pyrolysis displayed as hydrogen index versus oxygen index (Espitalié et al., 1977) for sediment samples from DSDP Sites 612 and 613. I, II, III are simplified kerogen classifications (e.g., Tissot et al., 1980).

(textinite). In the Pliocene sample (613-15-2, 120-134 cm), some algal debris was observed. However, these observations are based on very limited counts of kerogen particles.

The temperatures of maximum pyrolysis yield ( $T_{\max }$; Espitalié et al., 1977) range from 369 to $421^{\circ} \mathrm{C}$ (Table 1), indicating that the organic matter in all samples investigated was immature. This evaluation agrees well with the measured reflectance of primary vitrinite. The reflectance values are very low and range from 0.27 to 
Table 2. Vitrinite reflectance data for samples from DSDP Leg 95.

\begin{tabular}{|c|c|c|c|c|c|c|c|c|}
\hline \multirow{2}{*}{$\begin{array}{c}\text { Sample } \\
\text { (interval in cm) }\end{array}$} & \multirow{2}{*}{$\begin{array}{c}\text { Sub-bottom } \\
\text { depth }(\mathrm{m}) \\
\text { of top of } \\
\text { sample }\end{array}$} & \multicolumn{3}{|c|}{$\begin{array}{c}\text { Primary } \\
\text { vitrinite } \\
R_{\text {random }}(\%)\end{array}$} & \multicolumn{3}{|c|}{$\begin{array}{c}\text { Secondary } \\
\text { vitrinite } \\
R_{\text {random }}(\%)\end{array}$} & \multirow[b]{2}{*}{ Remarks } \\
\hline & & $\bar{x}$ & $\mathrm{~S}$ & $\mathrm{~N}$ & $\bar{x}$ & $\mathrm{~S}$ & $\mathrm{~N}$ & \\
\hline $612-10-3,120-134$ & 72.90 & & & & 0.66 & & 2 & \\
\hline $612-14-4,120-135$ & 113.20 & 0.27 & 0.02 & 10 & 0.57 & & 2 & Terrestrial plant tissue \\
\hline $612-62-3,120-133$ & 573.20 & & & & 0.61 & 0.05 & 9 & \\
\hline $612-67-5,120-133$ & 624.60 & 0.44 & 0.02 & 3 & 0.65 & 0.07 & 4 & \\
\hline $613-15-2,120-134$ & 224.20 & 0.42 & 0.02 & 5 & 0.58 & 0.05 & 19 & Algal debris \\
\hline
\end{tabular}

Note: $\overline{\mathrm{X}}=$ mean; $\mathrm{S}=$ standard deviation; $\mathrm{N}=$ number of measurements.

$0.44 \%$ (Table 2 ). The occurrence of secondary vitrinites $\left(R_{\text {random }}=0.57\right.$ to $\left.0.66 \%\right)$ indicates the presence of some redeposited material that is older and more mature.

\section{Extractable Organic Matter}

At Site 612, the amount of extractable organic matter is very low in the Maestrichtian samples (about $5 \mathrm{mg} / \mathrm{g}$ $\mathrm{C}_{\text {org }}$ ) and moderate in the Eocene to Pliocene samples ( 10 to $23 \mathrm{mg} / \mathrm{g} \mathrm{C}_{\text {org }}$ ). The highest value determined for the most organic-carbon-lean sample may result partly from the difficulty of weighing a low amount of extract precisely. The same is probably true for the Eocene samples from Site 613, for which the normalized extract yields range up to $52.4 \mathrm{mg} / \mathrm{g} \mathrm{C}_{\text {org }}$. The early Pliocene sample, in contrast, has the expected low extract yield of $7.4 \mathrm{mg} / \mathrm{g}$ $\mathrm{C}_{\text {org }}$ (Table 1). The percentages of liquid chromatography fractions of the organic-carbon-lean samples should also not be over-interpreted.

\section{Nonaromatic Hydrocarbon Composition}

A Pliocene and a late Miocene sample from Site 612 (Fig. 4) and a Pliocene sample from Site 613 (Fig. 5) were analyzed for their nonaromatic hydrocarbon compositions by capillary gas chromatography. All samples show a dominance of long-chain wax alkanes derived from terrestrial higher plants which have inherited their strong odd-carbon-numbered predominance from the biological system (Eglinton and Hamilton, 1963). Lowmolecular-weight $n$-alkanes and cyclic compounds are minor in each case. Gas chromatography/mass spectrometry of the samples revealed that most of the cyclic hydrocarbons identified (Appendix; Fig. 6) are either hopanoids or fernenes from bacterial sources (Ourisson et al., 1979; Brassell and Eglinton, 1983) or terpenoids probably derived from terrestrial higher plants (Kulshreshtha et al., 1972). The mass spectrum of two unidentified $C_{30}$ triterpanes are shown in Figures 7A and 7C. Two samples $(612-14-4,120-135 \mathrm{~cm}$ and $613-15-2,120-134 \mathrm{~cm})$ contain small amounts of tetracyclic terpanes probably derived from ring A degradation of 3-oxygenated triterpenoids of higher plants (Corbet, 1980; Corbet et al., 1980; Brassell and Eglinton, 1983).

Sterenes and steradienes were recognized only in Sample $613-15-2,120-134 \mathrm{~cm}$, but the concentrations were too small to identify most of them in the chromatogram (Fig. 5). Steroids are abundant in marine organisms (Mackenzie et al., 1982), and thus our observation is consistent with the microscopic observation of algal debris in this sample. The structures of some $\mathrm{C}_{28}$ and $\mathrm{C}_{29}$ steradienes (two isomers each) with a key fragment of $\mathrm{m} / \mathrm{z} 298$ (Fig. 7B; Appendix) could not be identified with confidence, although the mass spectra (Fig. 7B) resemble those of the $\mathrm{C}_{28}$ ster-5,24- or ster-5,24(28)-dienes found in deepsea sediments of the Gulf of California (Rullkötter et al., 1982).

The composition of the extractable nonaromatic hydrocarbons of the organic-carbon-lean samples was also screened by capillary gas chromatography, but it was found that most of these hydrocarbons were heavily contaminated with phthalate esters and hydrocarbons uncommon in immature deep-sea sediments (possibly from shipboard lubricants) and that the others were likely to be at least partly contaminated. Thus, these chromatograms are not reproduced here.

\section{CONCLUSIONS}

The organic matter in all of the sediment samples investigated from DSDP Sites 612 and 613 is predominantly terrigenous, as inferred from the low hydrogen index values, the visual kerogen description, and the dominance of long-chain wax alkanes from terrestrial higher plants in the extractable hydrocarbons. Unfortunately, the amounts of kerogen particles were too small to determine the proportions of terrestrial and marine organic matter quantitatively. The dominance of terrestrial organic matter may be the result of an increased supply of terrigenous matter, which in turn is due to the humid climatic conditions that have prevailed in North America since the Late Cretaceous (Hallam, 1984).

Although the high carbonate accumulation rates and high amounts of biogenic silica observed in the Eocene section of Sites 612 and 613 (Fig. 2; and site chapters, this volume) suggest high oceanic productivity, the content of organic matter is extremely low (less than $0.2 \%$ ). Together with extensive bioturbation (Fig. 2; and site chapters, this volume), well oxygenated deep-water conditions may have prevented the preservation of significant amounts of marine organic matter in the sediments.

The temperatures of maximum pyrolysis yield, the low vitrinite reflectance values, and the presence of olefins among the extractable hydrocarbons indicate that the organic matter in all samples investigated is very immature.

\section{ACKNOWLEDGMENTS}

We would like to thank Drs. M. Radke, P. J. Müller, and R. G. Schaefer for performing extraction/liquid chromatography, organic car- 

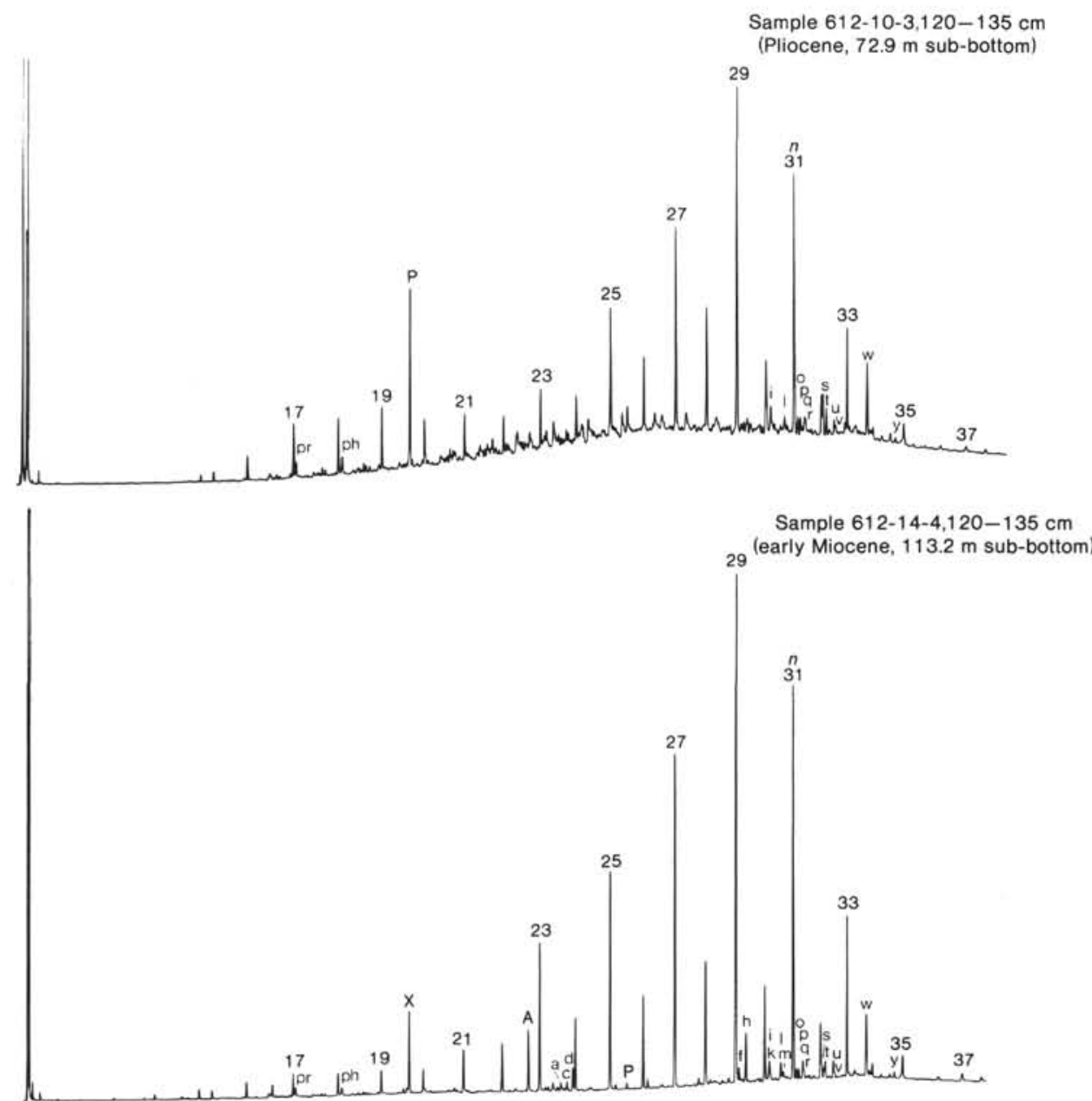

Figure 4. Capillary column gas chromatograms of the nonaromatic hydrocarbon fractions of two sediment samples from DSDP Site 612 . Numbers indicate $n$-alkanes; lettered compounds were identified by GC/MS and are listed in the Appendix.

bon analyses and Rock-Eval pyrolysis, and gas chromatography, respectively. We thank W. Benders, U. Disko, F.-J. Keller, and K. Sellinghoff for technical assistance. Financial support by the Deutsche Forschungsgemeinschaft (Grant No. We 346-25) is gratefully acknowledged.

\section{REFERENCES}

Boyce, R. E., 1972. Carbon and carbonate analyses, Leg 11. In Hollister, C. D., Ewing, J. I., et al., Init. Repts. DSDP, 11: Washington (U.S. Govt. Printing Office), 1059-1071.

Brassell, S. C., and Eglinton, G., 1983. Steroids and triterpenoids in deep sea sediments as environmental and diagenetic indicators. In Bjorфy, M., et al. (Eds.), Advances in Organic Geochemistry-1981: Chichester (Wiley), pp. 684-697.

Corbet, B., 1980. Origine et transformation de triterpènes dans des sédiments récents [Thèse]. University of Strasbourg.

Corbet, B., Albrecht, P., and Ourisson, G., 1980. Photochemical or photomimetic fossil triterpenoids in sediments and petroleum. $J$. Am. Chem. Soc., 102:1171-1173.

Eglinton, G., Hamilton, R. J., 1963. The distribution of alkanes. In Swain, T. (Ed.), Chemical Plant Taxonomy: London (Academic Press), pp. 187-217.

Espitalié, J., Laporte, J. L., Madec, M., Marquis, F., Leplat, P., Paulet, J., and Boutefeu, A., 1977. Méthode rapide de caractérisation des roches-mères, de leur potentiel pétrolier et de leur degré d'évolution. Rev. Inst. Fr. Pet, 32:23-42.

Hallam, A., 1984. Continental humid and arid zones during the Jurassic and Cretaceous. Palaeogeogr., Palaeoclim., Palaeoecol., 47: 195-223.

Katz, B. J., 1983. Limitations of 'Rock-Eval' pyrolysis for typing organic matter. Org. Geochem., 4:195-199.
Kulshreshtha, M. J., Kulshreshtha, D. K., and Rastogi, R. P., 1972. The triterpenoids. Phytochemistry, 11:2369-2381.

Mackenzie, A. S., Brassell, S. C., Eglinton, G., and Maxwell, J. R., 1982. Chemical fossils: the geological fate of steriods. Science (Washington D.C.), 217:491-504.

Ourisson, G., Albrecht, P., and Rohmer, M., 1979. The hopanoids. Palaeochemistry and biochemistry of a group of natural products. Pure Appl. Chem., 51:709-729.

Radke, M., Sittardt, H. G., and Welte D. H., 1978. Removal of soluble organic matter from rock samples with a flow-through extraction cell. Anal. Chem., 50:663-665.

Radke, M., Willsch, H., and Welte D. H., 1980. Preparative hydrocarbon group type determination by automated medium pressure liquid chromatography. Anal. Chem., 52:406-411.

Roucaché, J., Deroo, G., and Boulet, R., 1979. Caractéristation par différentes méthodes physico-chimiques de types de matière organique dans des sédiments du Crétacé d'Atlantique en mer profonde. Rev. Inst. Fr. Petrol., 34:191-220.

Rullkötter, J., von der Dick, H., and Welte, D. H., 1982. Organic petrography and extractable hydrocarbons of sediments from the Gulf of California, Deep Sea Drilling Project Leg 64. In Curray, J. R., Moore, D. G., et al., Init. Repts. DSDP, 64, Pt. 2: Washington (U.S. Govt. Printing Office), 837-853.

Tissot, B., Demaison, G., Masson, P., Delteil, J. R., and Combaz, A., 1980. Paleoenvironment and petroleum potential of middle Cretaceous black shales in Atlantic basins. Am. Assoc. Pet. Geol. Bull., 64:2051-1063.

Date of Initial Receipt: 1 May 1985

Date of Acceptance: 8 January 1986 


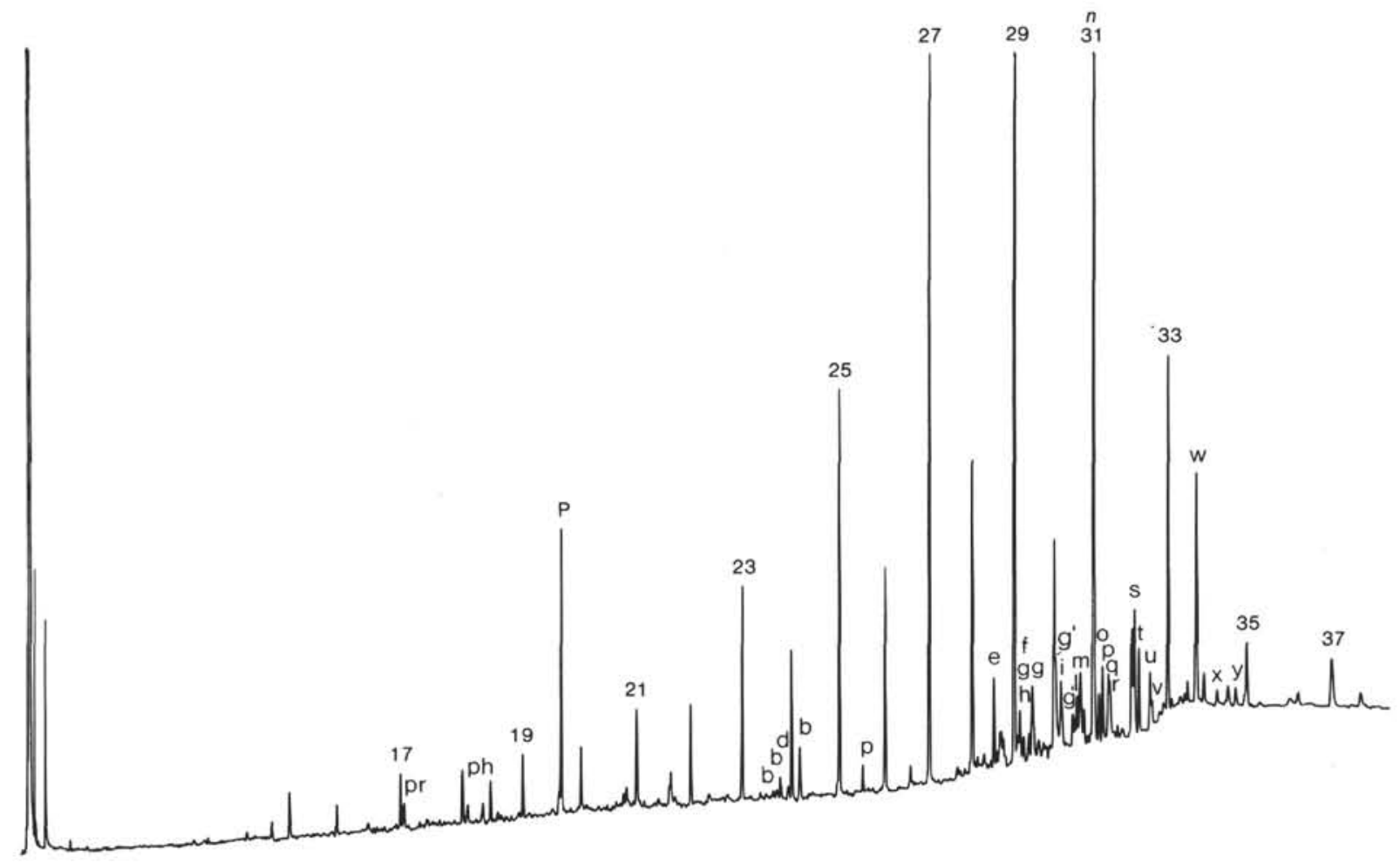

Figure 5. Capillary column gas chromatogram of the nonaromatic hydrocarbon fraction of Sample 613-15-2, 120-134 cm (early Pliocene, $224.2 \mathrm{~m}$ sub-bottom). Numbers indicate $n$-alkanes; lettered compounds were identified by GC/MS and are listed in the Appendix.<smiles>CC1=CCCC2C1CCC1C2CCC23CCC(C(C)C)C2C13</smiles>

1<smiles>CC(C)C1CCC2CC[C@]3(C)CCCC(C)C3CCC21</smiles>

II<smiles>CC1CCC2C3CCC4C(C)(C)CCCC4(C)C3CCC12C</smiles>

III

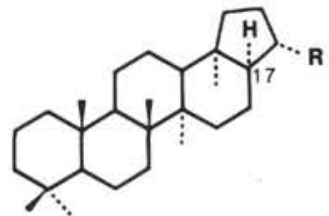

IV<smiles>[R]C(C)C1=C2CCC3(C)C(CCC4C3CCC3C(C)(C)CCC[C@]43C)C2CC1</smiles>

V<smiles>CC(C)[C@H]1CC[C@]2(C)C3CC[C@]4(C)C5CCC6C(C)(C)CCC[C@]6(C)C5CC[C@]4(C)C3CC[C@]12C</smiles>

VIII

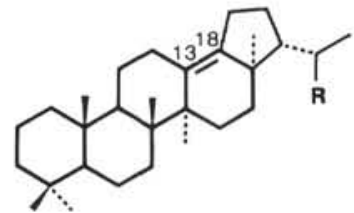

VI

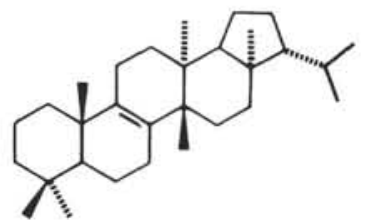

IX

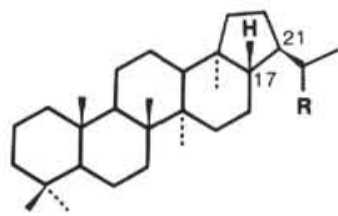

VII<smiles>CC(C)[C@H]1CCC2[C@]1(C)CC[C@]1(C)C3CCC4C(C)(C)CCC[C@]4(C)C3=CC[C@]21C</smiles>

$\mathrm{X}$

Figure 6. Structural formulae of compounds identified by GC/MS. For an explanation of the numbering see the Appendix. 

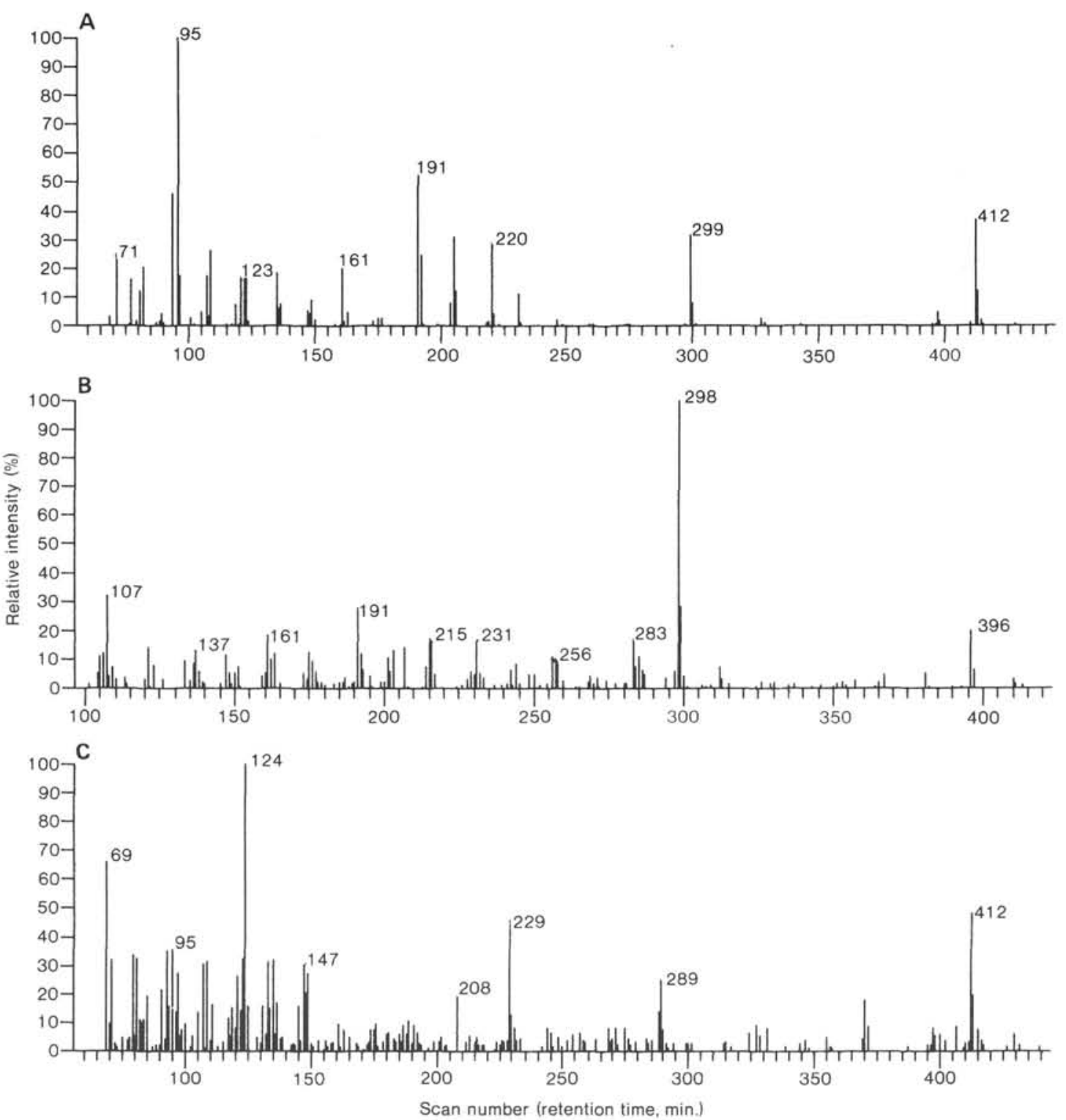

Figure 7. Mass spectra of unidentified components in the nonaromatic hydrocarbon fraction of Sample 613-15-2, 120-134 $\mathrm{cm}$. A. $\mathrm{C}_{30}$ triterpane (e in Fig. 5). B. $\mathrm{C}_{29}$ steradiene (second-eluting $\mathrm{g}^{\prime}$ in Fig. 5), possibly a ster-5,24-diene or ster5,24(28)-diene. C. $\mathrm{C}_{30}$-triterpane ( $\mathrm{x}$ in Fig. 5). All spectra are background subtracted, and the quality of spectra $\mathrm{B}$ and $\mathrm{C}$ is fairly poor as a result of the low concentrations. 
APPENDIX

Branched and Cyclic Hydrocarbons Detected in the Nonaromatic

Hydrocarbon Fractions of Sediments from DSDP Sites 612 and $613^{\mathrm{a}}$

\begin{tabular}{|c|c|c|c|}
\hline & Compound & Mass spectrometry data & Structure \\
\hline $\mathrm{pr}$ & pristane & & \\
\hline $\mathrm{ph}$ & phytane & & \\
\hline a & nor-de-A-lupane? & $\left(\mathrm{M}^{+} 316,273,192,177, \mathrm{BP} 109\right)$ & \\
\hline b & tetracyclic terpenes & $\left(\mathrm{M}^{+} 326,311,255,108, \mathrm{BP} 95\right)$ & \\
\hline c & de-A-lup-5(10)-ene & & I \\
\hline $\mathrm{d}$ & de-A-10 $\beta(\mathrm{H})$-lupane & & II \\
\hline e & $\mathrm{C}_{30}$ triterpane & $\left(\mathrm{M}^{+} 412,299,191\right)$ & \\
\hline f & $17 \beta(\mathrm{H})$-trisnorhopane & & III, $\mathrm{R}=\mathrm{H}$ \\
\hline g & $\mathrm{C}_{28}$ steradiene & $\left(\mathrm{M}^{+} 382,298,255\right)$ & \\
\hline$g^{\prime}$ & $\mathrm{C}_{29}$ steradiene & $\left(\mathrm{M}^{+} 396,298,255\right)$ & \\
\hline $\mathrm{h}$ & unknown & $\left(\mathrm{M}^{+} 400\right)$ & \\
\hline i & $17(\mathrm{H})$-norhopane & & IV, $\mathrm{R}=\mathrm{H}$ \\
\hline j & norhop-17(21)-ene & & $V, R=H$ \\
\hline $\mathrm{k}$ & norneohop-13(18)-ene & & VI, $\mathrm{R}=\mathrm{H}$ \\
\hline 1 & hop-17(21)-ene & & $\mathrm{V}, \mathrm{R}=\mathrm{CH}_{3}$ \\
\hline $\mathrm{m}$ & normoretane & & VII, $\mathrm{R}=\mathrm{H}$ \\
\hline $\mathrm{n}$ & $17(\mathrm{H})$-hopane & & IV, $\mathrm{R}=\mathrm{CH}_{3}$ \\
\hline o & fern-7-ene & & VIII \\
\hline $\mathrm{p}$ & neohop-13(18)-ene & & VI, $\mathrm{R}=\mathrm{CH}_{3}$ \\
\hline$q$ & $17 \beta(\mathrm{H})$-norhopane & & III, $\mathrm{R}=\mathrm{C}_{2} \mathrm{H}_{5}$ \\
\hline $\mathrm{r}$ & fern-8-ene & & IX \\
\hline s & fern-9(11)-ene & & $\mathrm{x}$ \\
\hline $\mathrm{t}$ & $17(\mathrm{H})$-homohopane (22R) & & $\mathrm{IV}, \mathrm{R}=\mathrm{C}_{2} \mathrm{H}_{5}$ \\
\hline u & $17 \beta(\mathrm{H})$-hopane & & III, $\mathrm{R}=\mathrm{CH}\left(\mathrm{CH}_{3}\right)_{2}$ \\
\hline $\mathrm{v}$ & homomoretane & & VII, $\mathrm{R}=\mathrm{C}_{2} \mathrm{H}_{5}$ \\
\hline $\mathrm{w}$ & $17 \beta(\mathrm{H})$-homohopane & & III, $\mathrm{R}=\mathrm{CH}\left(\mathrm{CH}_{3}\right) \mathrm{C}_{2} \mathrm{H}_{5}$ \\
\hline $\mathrm{x}$ & $\mathrm{C}_{30}$ triterpane & $\left(\mathrm{M}^{+} 412\right)$ & \\
\hline y & $17 \beta(\mathrm{H})$-bishomohopane & & III, $\mathrm{R}=\mathrm{CH}\left(\mathrm{CH}_{3}\right) \mathrm{C}_{3} \mathrm{H}_{7}$ \\
\hline A & $\begin{array}{l}\text { aromatic hydrocarbon } \\
\text { (incomplete separation) }\end{array}$ & & \\
\hline $\mathbf{P}$ & phthalate & & \\
\hline
\end{tabular}

${ }^{a}$ Gas chromatograms are shown in Figs. 5 and 6. Structural formulae are given in Fig. 7. $\mathrm{M}^{+}$ $=$ molecular ion, $\mathrm{BP}=$ base peak. 